REZGA KOUIDER* , JULIA IVASHKO**

\title{
Study Methodology of the Architectural Periodization of Algerian Mosques and the Ritual Role of Elements (Mihrab, Minbar, Oibla, Bath for Ablution) in the Islamic Worship Service
}

Abstract

The article introduces a study methodology of the architectural periodization of Algerian mosques based on the systematic structural analysis. The specificity of the Islamic architectural school of Algeria is the simultaneous combination of the traditions of many cultures, imported from other countries, and local, different within certain regions. In the cities of Algeria, mosques with different spatial organization have survived: the so-called Arabian column type, the Maghes Algeria is devoted to ritual ablutio

Keywords: mosques of Algeria, architectural periodization, system-structural analysis, water, ritual ablution

\section{Introduction}

The Islamic architecture of the Maghreb countries (Tunis, Algeria, Morocco) was formed at the junction of many cultures - both imported from outside and based on national traditions. The specificity of Islamic architecture consists in the fact that not only the facade of a separate object is a carrier of semantic information but the object as a whole (facade, plan, interior al and decorative art), the whole aggregate types of of sever mo has objects (comiex, ensemble), urban formation (stret, square, quanter, distict, a comprehensive study of the Islamic architectural school of Algeria provides for consideration at various hierarchical levels - from the enlarged town-planning to facility and elementby-element levels. Taking into consideration the multiplicity of external influences (Romanesque, since North Africa belonged to the territories of the Roman Empire, Arab, Persian, Spanish, Portuguese, Ottoman and Byzantine) and the diversity of local culture (Maghreb, Kharijites), it is necessary to analyse the architecture of mosques on the basis of systematic structural analysis, by dividing the whole object into its component parts - aspects, components and elements. Several structural and logical models describing external and internal surfaces, types of monumental and decorative art, and etc. are being created. The principle of creating such models is demonstrated on the example of the model of external surfaces - the facade of the object of architecture.

In order to obtain an objective assessment of the specificity of the architecture of Algerian mosques, the facade is divided into hierarchical levels, from abstract (vertical and horizontal divisions) to concrete (silhouette, scale, tectonics, individual elements of the façade). The generalized information model which has been created on the basis of system-structural analysis provides for the analysis of facades with division into hierarchica levels of elements and, accordingly, style indicators. The information model consists of two tables, the first of which describes the style tables, the first of which describes the style indicators (vertical and herzontal divisions), and facade a different hierachical levels. At first, facade at different hierarchical levels. At first, all possible variants of vertical facings of the facade are detected in accordance with the number of axes - separately for symmetry and asymmetry and horizontal divisions. The main components of the facade of any building are a roof, a crown and a wall, which are the largest elements - the components of the building facade. The second level of elements, the so called "Elements of elements" includes smaller elements-components of large elements.

Addition of the system-structural analysis method to the traditionally used techniques provides an opportunity:

1) to substantiate the thesis about the presence (or absence) of borrowings at the leve of abstract (vertical and horizontal division in composition, articular (individual façade components according to their location on the facade, the presence of common and original techniques, form and its filling, compared with elements of other styles, in different periods of the construction of Algerian mosques, within the main centres and regional centres):

2) To identify borrowings within an individual element by dividing it into a set of interrelated elements and comparing the elements of the corresponding levels with each oth 3) To identify architectural techniques common with archithe modifiction f borrow techiques and originat techiques that had no analogues abroad:

is 5) The graphical and andycal base of the research is considered as a catalogue of typical architectural techniques, elements and detals of the lslamic architectural school of Algeria. Not individual elements were investigated, but elements as interrelased components of the facade.

On the basis of the system approach, signs of national identity are determined in the mosques of Algeria, and it was defined territories with vivid manifestations of national signs in mosques and territories with the presence of architecture and construction traditions introduced from outside.

\section{Main Part}

1. State Policy in the Field of Protection of the National Cultural Heritage and a Range of Uncertain Issues

Nowadays in Algeria there are more than 17,000 old and new mosques, most of which date back many centuries. The national identity of the Islamic architectural heritage of Algeria is evidenced by the fact that, despite the external political, cultural and architectural influences from other states, from the early period and up to the period of French colonization, an authentic, based on the national Maghreb traditions, type of simple (according to the volumetric and spatial composiion) mosque without decoration on the facales and with specific, square minaret-tower has been preserved. Other typical national mosques in Algeria are the mosques of Kharijites, concentrated in the M'zab valley.

列 protection and restoration of the heritage of Islamic architecture, which is regulated by the following laws and state programs: Algeria has ratified the Convention for the Protection of the World Cultural and Natural Heritage (17.12.1975), the International Convention for the Safeguarding of the Intangible Cultural Heritage (20.04 2006), the Convention on the Protection and Promotion of Cultural Expressions of 2005 (26.05.2005). Among the regional decuments, it should be mentioned the Cultural Charter for Africa (19.09.1990).

At the 64th session of the United Nations General Assembly (22 July 2009) the of the United Nations General Assembly (22 July 2009), the information was submitted in accordance With General Assembly Resolution 65/155 (10.07.2009) from the Government of Algeria on

1. The Government of Algeria regards cultural diversity as one of the main components of civilizations and cultures. Algeria has ratified a number of international docuof cultural heritage. In addition, Algeria has adopted the relevant laws to consolidate its international obligations in domestic legislation.

2. Algeria has developed a partnership strategy in the field of culture. The country is on of the organizers and venue of important cultural events, such as the Pan-African Cultura Festival and participates in various international cultura initiatives (including the preparation of a feasibility study for the establishrion the restoration of the Museum of the Great African Culture in Algiers.

3. Respect to cultural diversity is laid down in the Constitution of Algeria.

4. At the level of the various institutions in Algeria, a number of bodies has been established that are engaged in the scientific research and the promolion of national cultures in order to ensure diversity, international cultural exchanges, cooperation and the conservation of nature reserves.

\section{1. The El-Bey Mohamed El-Kebir Mosque (1792, the
city of Oran) photo: Rezge Kouider, 2018}

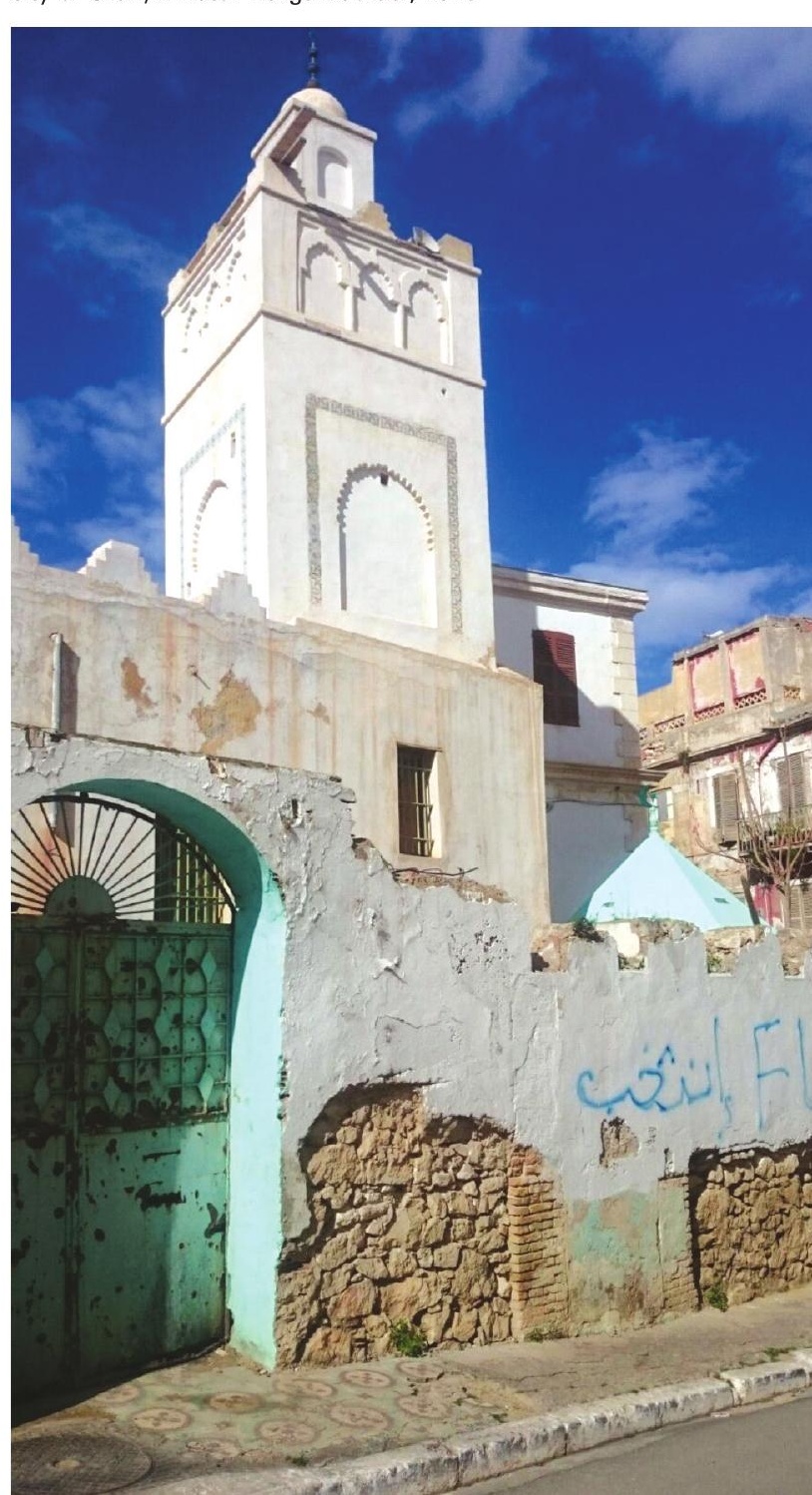




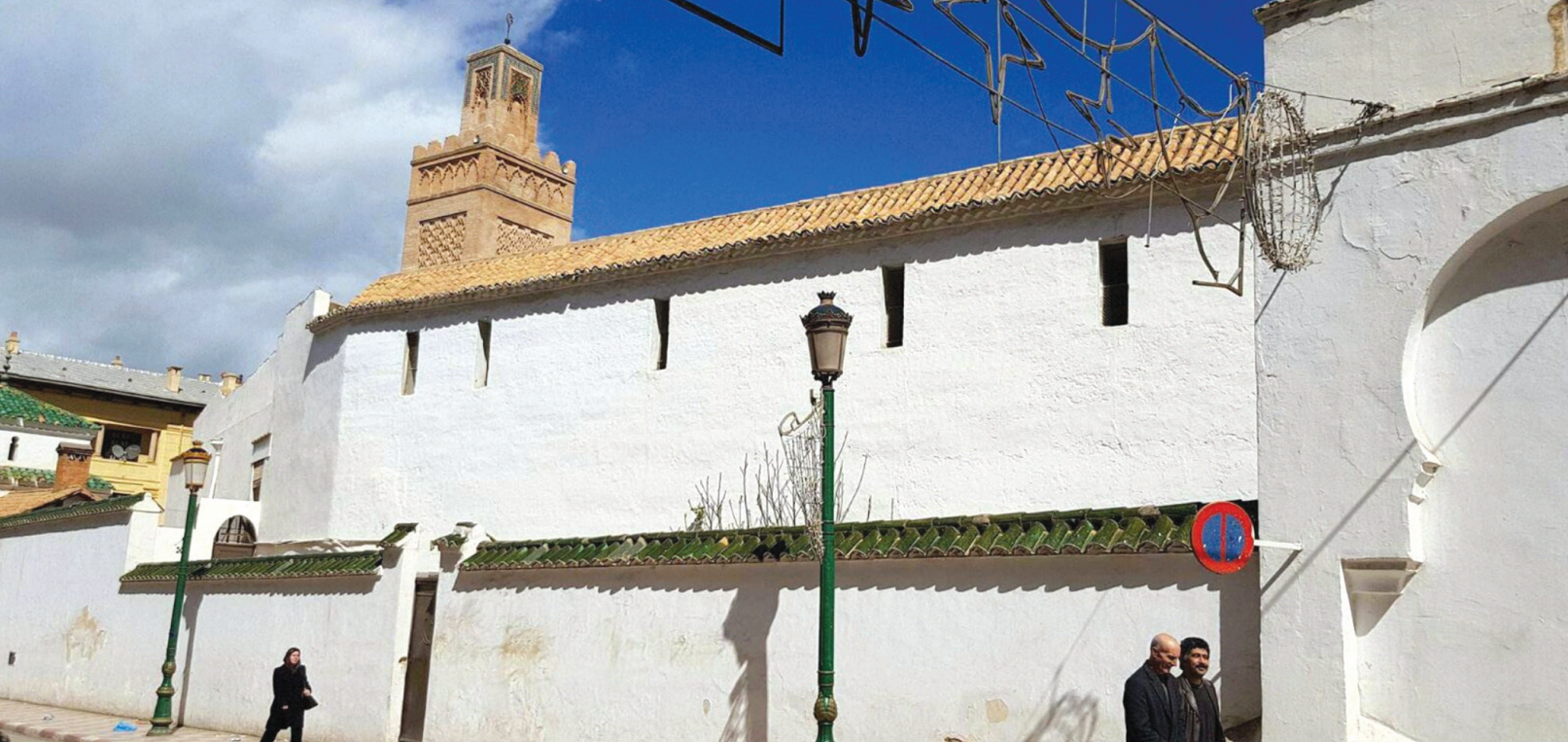

III. 2. The Great Mosque of Tlemcen (1136, minaret 1236). Photo: Rezga Kouider, 2018

5. Algeria allocates additional resources to provide various forms of cultural expression and the formation of a new infrastructure in the cultural sphere that includes museums, theatres, cinemas, libraries and cultural centres.

Thus, the topic of the research is consistent with the state policy in the field of development of national identity and the exchange of cultural traditions. In comparison with the mosques of other Muslim countries, the mosques of Algeria are much less known. The uniqueness of Algerian mosques is that their architecture was formed at the junction of many cultures at the same time (Fig. 1.2)

The analysis of the source database made it possible to identify a number of unresolved issues:

1) Complete information about the Algerian mosques is contained mainly in Arabic and French-language sources, which significantly restricts the audience of scientists- readers;

2) The architectural periodization of Algerian mosques is not determined in comparison with the historical periodization; 3) The simultaneous impact of historical events, ethnographic and natural-climatic features to the mosques of different regions is not justified, and it is not proved how these factors contributed to the regional identity of the mosques of different regions; 4) The generalized schemes of the architectura deverions; of Algerian mosques have not been developed, considering of Algerian mosques have not been devel
periodization and ethnographic zoning;

5) The signs of the national identity of the Islamic architectural school of Algeria are not formulated on the basis of the system-structural analysis; they do not state what exactly is the general and distinct between the Islamic architectural school of Algeria and neighbouring countries.

2. Historical periodization and architectural periodization of Algerian mosques

The historical periodization of Algeria is as follows. In total thirteen historical periods are distinguished:

1) 7th century (647) - the first Arab invasion, the invasion of Uqbah ibn Nâfi (the Arabs reign);

2) 776-909 - the rule of the Rostemid dynasty (the Rustamids) (Kharijism) (reign of the Persians from Basra);
3) 909-972 - the reign of the Fatimid dynasty

4) 972-1148 (1163) - the reign of the Zirid dybers of the Middle Maghreb-Algeria);

5) 1007-1152 - the reign of the Hammadids (the reign of local rulers from the Berbers of the Middle Maghreb-Algeria);

6) the mid.- 11th century. - The second Arab invasion

7) 1052-1147 - reign of the dynasty of the from the Berbers of the Western MaghrebMorocco);

8) 1147-1235 (1269) - the reign of the Almo-

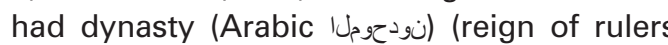
from the Berbers of the Western MaghrebMorocco)

9) 1215-1485 - reign of the Marinid dynasty (the Merinids) (reign of rulers from the Berbers of the Western Maghreb-Morocco)

10) 1235-1556 - the reign of the Abd dids (the Zayyanid dynasty dids (the Zayyanid dynasty, Banu Zian) (the reign of rulers from the Berbers of the Middle
Maghreb-Algeria);

11) The end of the 15th -16th centuries. - the appearance on the Atlantic coast of the Spanitories and the constuct the seilies and forritories and the construction of cities and fortresses;

12) 1554-1830 - the rule of the Ottoman Empire 13) 1830-1962 - French colonization.

Islamic architectural schools were formed in a close relationship between the canons of Islam and its own and borrowed architectural construction and artistic traditions. The mos ancient of all Islamic architectural schools is the Syrian-Egyptian (Arabic). There is a version that the specificity of canonical praying in (reign of the Arabs) nasty (the reign of local rulers from the BerAlmoravids (Arabic نوطبارمنا) (reign of rulers the open air was due to local natural and climatic conditions, which did not require any protection outside the walls. The prayer courtyard of the Prophet Muhammad was a prototype of the cathedral and Friday mosque. K.A.C Creswell put forward a version of the continuity of the open prayer house of the Prophet Muhammad from the prehistoric home of the tribal chief. It was in Medina that during the lifetime of Muhammad, three main signs of the cathedral mosque - mihrab minbar and minaret, were born [2, p.103]. The minaret was proposed by the Prophet to call the believers to prayer, literally the word "minaret" means "Manara" - "the place from which the light comes" or "lighthouse" Such high tower-min

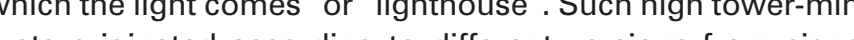
ersions from signa owers or from Chistian bell towers.

Islam: Arabic (Syrian-Egyptian), Maghreb, Persian, Indian, Ottoman [1, 2].

The oldest of them is the A ab othool, which schools of Istam in the eary peiod, spreading the hyposyle type of the mosque overy period, spreading the hypostyle type of the mosque over numerous territories. The Persian school has formed a specific iwan type of a mosque with a modified chartak and a large open courtyard, the Ottoma school has introduced a central-domed type of mosque, de rived from Christian churches of Byzantine architecture $[1,2]$. The specific line of the hypostyle mosques of the Arabian type was developed in the Maghreb countries [1, pp.100-109; 2 pp.136-153]. This type of hypostyle mosque with a rectangular plan remained widespread up to the Ottoman conquest in the XVI century [1, pp. 9-25; 2, pp. 90-190]. A. Muller described how the open prayer court of the Prophet was gradually transformed into a hypostyle mosque [3].

According to their type, the hypostyle mosques are the early Algerian mosques of Sidi-Ghanim Mosque in Mila (649), the Great Mosque of Algiers (1096) (Djama'a al-Kebir in Algiers) of the rectangular plan with eleven naves, perpendicular to the Oibla, a small inner courtyard and the arcade like the Koutoubia or Kutubiyy Mosque in Marrakesh and the the Koutoubia or Kutubiyy Mosque in Marrakesh and the Great city of Tlemcen) with a cut off corner of a rectanguler a squere couryard, thireen naves. In the example of a squar of the Gers of different times within the same building: first mosque had a rectangur plan and modest mosque had a rectangular plan and modest size and a regular rectangular counyard; after the construction of the vicar's palace near the palace, the expansion of the mosque was hampered, later in the 12th century the central nave of the mosque was magnificently decorated with a pair of domes on ibs and consoles; brick decoralion of ribs made of bricks on an edge form thin intersecting arcs, the area between these arcs is made of carved alabaster ornament; there are smal stalactite works in the shell of the dome over the corners of the quadrangular frame and there is a stalactite calotte at the zenith, the semi-dome of the mihrab is arranged on an octagonal drum and is decorated with ray flutes. [1, pp.79-80]. Considering the fact that the North of Africa belonged to the colonies of the Roman Empire, afterwards a constant change of dynasties that ruled Algeria during the 7th-19th centuries, among which were Arab dynasties, Persian, local Berber, Ot- toman, and also colonization of the Spaniards, French, multi-ethnic compositio of cities on the coast of Algeria during the Ottoman rule, it can be argued that the architectural Islamic school of Algeria was formed at the junction of many cultures at once.

The periodization of mosques is as follows:

1) the first period $-1-6$ historical periods $(647$ - the middle of 11 th century):

The simultaneous presence of Arab, local Persian, Iraqi influences, the constuction mosques of the Arabian hypostyle type;

The Sidi Okba mosque in the village of Sidi Okba is $20 \mathrm{~km}$ away from the city of Biskra (1073, renovated in 1665); it is dated by the the period of the reign of the Zirids (local rulers from the Berbers of the Middle MaghrebAlgeria) 972-1148 (1163). This mosque was built by Al-Mu'izz ibn Bads following the pattern of the plan of the Prophet's mosque in Medina. This is the only example of such a constructive scheme in Algeria and it is inherently borrowed from Medina. The size of the mosque is $59.4 \times 36.6 \mathrm{~m}$

The main features: a hypostyle type, simple non-decorated facades with pointed and rectangular slits; dominant - square-shaped minaret crowned with a tier-tower; a horizontal outstretched silhouette of a mosque with an undeveloped cylindrical dome, contrasts with the active vertical of the minaret; the seven naves are parallel to the wall of the Qibla; in the interior, quite simple in decoration, it is applied the system of faceted columns between naves with cast chaplets on the lime mortar, on which the undecorated horseshoe arches are based. Materials: tone, timber, palm trunks, plaster, lime, ceks, plaster, lime, ce

Henmad Fort (the Al Qal'a of Beni Hammad mosque) in the Hodna mountains, on the southern slope of Mount Taqarbūst, is dated back to the Hammadids period (local rulers from the Berbers of the Middle Maghreb, Algeria) (1007-1152). The first stage of construction 1007-1008 years, the second stage 1062-1089years, the third stage - the second quarter of the 12th century; the minaret was restored in 1974). The first stage of construction is connected with Hammad ibn Buluggin (Bologin), the second stage of construction is connected with the emir Al-Manșūr ibn alNășir. Dimensions of the mosque are $64 \mathrm{~m} \times$ $56 \mathrm{~m}$, the height of the square-shaped minaret is $25 \mathrm{~m}$. Planning according to the type of the Great Mosque of Cordoba and the the Great Mosque of Kairouan. 
The Sidi Bou Merouáne mosque in Annaba (1033), the height of the minaret $-17.5 \mathrm{~m}$, was built by Al-Mu'izz ibn Bādīs during the reign of Hammadids.

The Great Mosque of Constantine (1135) with a two-tier minaret built by Yahya ibn Tamim ibn Al-Mu'iz ibn Badis, belongs to the same period. The dimensions of the rectangular plan are $24 \times 22.10 \mathrm{~m}$, the height of the minaret is $25 \mathrm{~m}$. The plan of the prayer hall has six naves (central, three to the right of the mihrab and two on the left): the mihrab is cre right of the mihrab and two on the left), the mihrab is crowned by semi-dome; capitals with stylized Acanthus leave and lateral volutes. The mosque has the main façade, which goes outside. The facade is decorad with a central arch of the entrance with an increas main entrance with a horseshoe arch is magnificently decorated with decor.

The main features: the reminiscence of ancient Roman traditions to decorate with cylindrical marble columns with a styltions to decorate with cylindrical marble columns with a styl-
ized Corinthian order; materials - brick, stone, wood, plaster, ized Corinthian order; materials - brick, stone, wood, plaster,
marble, plaster, ceramic décor; minarets - square at the base marble, plaster, ceramic decor; minarets - square at the base
or square terraced with conical crown; an inner sahn (courtor square terraced with conical crown; an inner sahn (court-
yard) with a fountain.

2) the second period (the period of the Almoravids) - the 7th period (1052-1147) (Influence of the Andalusian architecture, the Caliphate of Cordoba, the occurrence of large decoration): The mosques of the 10th -11 th centuries are similar in design to Tunisian mosques; the influence of Andalusian art on the city of Oran, Ténès, Cherchell and Algiers. The mosques of the Old Ténès and Ashir, the Al Oal'a of Beni Hammad Mosque, in Annaba (formerly known as Bona) (in the style of the Sidi Okba Mosque in Kairouan in terms of both - the plan and the three-tiered composition of the minaret; the intersecting cross vaults, the columns), the Great Mosque of Algiers or Djama'a al-Kebir, the Great mosque of Nedroma, the Great Mosque of Tlemcen.

The Great Mosque of Algiers or Djama'a al-Kebir in the city of Algiers was built during the reign of the Almoravids by Ali ibn Yusuf ibn Tashin; it has a recign of the Almoravids by Ali ibn Yusuf ibn Talt duing the reign of the Almorated horizonthe at a leads to the min ab, is wicr and iscrow are perpendicular to the Qibla wall, a rectangular inner courtyard, in its interior it is un the system of square and crossing-square pilars, which support undecorated horseshoe arches. In contrast to the simple interior of the prayer hall, the mihrab is magnificently decorated with ornaments and spiral columns. The square -based minaret in the northeast corner of the mosque belongs to a later period, it is crowned with the stepped merlons and a roof lantern, the surface of the walls is decorated with decorative niches of rectangular shape, arches and blue-and-white ceramic inserts.

The Great Mosque of Tlemcen or Djama'a al-Kebir in the city of Tlemcen (1136) with a minaret (1236), was built by Ali ibn Yusuf ibn ibn Tashfin, belongs to the period of reign of the Almoravids. Its dimensions are $60 \times 50 \mathrm{~m}$, the height of the minaret is $29.15 \mathrm{~m}$. It is decorated with: marble, carved plaster, arches of complex forms; an inner courtyard with a fountain, surrounded on four sides by galleries with fake niches of complex shape; two ribbed domes, one of which is in front of the mihrab with 12 thin ribs; a dome with stalactites above the centre; each tier of the mosque is crowned with a double sloping roof covered with glazed tiles.

The main features: a hypostyle type without a large open courtyard with a swimming poo (the Great Mosque of Algiers, 1096-1097, the Great Mosque of Tlemcen, 11th-12th centuries) - a rectangular plan with transverse naves running wall " "forest" perpendicular to the Qibla wall a "fosm of columns with horseshoeshaped arehes in collo tubiya Mosque in Marrakesh), the naves are rows of multion rows of multilobed arches, in 1322 a minare was added. In the 12th century it was decorated with carved cantilevers and domes on ribs (ribs, made of bricks on the edge, form 12 thin crossed arcs with a transparent ornament of through the alabaster pattern); materials - stone, brick, tile, ceramic tiles, timber stalactite tromps over the over the corners of the quadrangular frame in the dome shell, there is a stalactite calotte at the zenith; the semi-dome of mihrab on an octagonal drum with ray cannelures. Two types of mosques are used for planning - with naves parallel to the wall of the Qibla, similar to the type of the Mosque in Medina (the Ténès Mosque, the Sidi Okba Mosque) and the so-called Andalusian type of mosque similar to the type of the Great Mosque of Cordoba, when the nave are perpendicular to the Qibla;

3 ) the third period (the Almohads period) - the 8th historical period - 1147-1235 (1269) (marked by the emphasized religiosity of the rulers): The stylistics of mosques of this period a The stylistics of mosques of this period are similar to the second period, however the portions, they have, with more elegant proportions, they have a rectangular courtyard dinare are high in the form of square towers decorated with a simple geometric pattern. The motif of the horseshoe irregular-shaped a) 4) the fourth period (the period of Merinids and Abd al-Wadids ) - 9th -10th historical period (1147-1485)

This period did not play a significant role in the periodization of Algerian mosques, bu this period was marked by the active construction of medrese/madrassahs.

12th-14th centuries:

Sidi Abdallah ibn Djafar Mosque in the village of Tafessera (the 12th century);

the Mosque of Sidi bel Hassan in Tlemcen (1296)
Sidi Brahim Mosque in Tlemcen (13th century); - the Mechouar Mosque and minaret in Tlemcen (the end of the 10th century - beginning of the 14th century):

the mosque of the city of New Tlemcen or Mansourah Mosque (from 1303):

the Hassan Tower in Rabat, Morocco

- the El-Ebbad mosque in the village of El-Ebbad (Eubbad) (1339);

the Sidi Boumédiène mosque (1339):

- the Sidi Abdallah ibn Djafar mosque in Bani Snous (14th15 th centuries), at the turn of 4-5 periods.

During the reign of the Marinid dynasty (the Merinids) (rulers from the Berbers of the Western Maghreb-Morocco) (12151485), the El-Eubbad Mosque in the village of El-Eubbad (1339) and the Sidi Boumédiène Mosque (1339) were built. The El-Ebbad Mosque was built by Sultan Abu Al-Hasan with brick, stone and tile, with a decor of marble, plaster, timber, ceramics and bronze. In plan its size is $28.45 \times 18.9 \mathrm{~m}$, the height of the minaret decorated with mosaic and honeycomb panels, is $27.5 \mathrm{~m}$. The prayer hall is five-nave, each of the naves is perpendicular to the wall of the Cibla, the naves are divided by rows of horseshoe-shaped arches on rectangularbased columns, the central nave that leads to the mihrab is wider. The mosque has a rectangular courtyard with a fountain in the centre. On the sides the fountain is surrounded by four galleries of horseshoe-shaped arches. Some of the exterior walls are decorated with ceramics. Mihrab is crowned with a dome. In the decoration it is felt the influence of the architecture of the mosque Kutubiyya from Marrakesh.

During the same period of the reign of Marinids Abu Inan Faris, the Sidi al-Haloui mosque was built in Tlemcen (1355) the size of which is $27.5 \times 17.4 \mathrm{~m}$ in terms of plan, there is an inner courtyard; stone, brick, and marble and plaster were used during its construction.

During the reign of the Abd al-Wadids (the Zayyanid dynasty, Banu Zian) (the reign of rulers from the Berbers of the Middle Maghreb-Aleria) (1235-1556), on the order of 'Abdalla ib Diaf Difor Mosque was

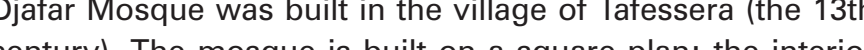
cerce space has the naves perpendicular to the wall of the Qibla, cover wh a four soper roof. The square -based pillars are in derlinked through the horseshoe-shaped arches, a mihrab is decorated with a magnifice ty or mamented horseshoeshaped arch on two pillars; in front of the niche of mihrab there is a $7 \mathrm{~m}$ high dome open to the zenith; the minaret covered with a tile is $12 \mathrm{~m}$ high, and it is by the nature of the minaret that you can establish the affiliation of the mosque to the period of the Abd al-Wadids rule.

The Mosque of Sidi bel Hassan in Tlemcen belonging to the period of the Abd al-Wadids rule, was erected by Sultan Uthman I and Abu Ibrahim Ibn Yahya Yaghmurasan with the use of brick, stone, marble, plaster, tiles. The mosque is small, by the plan its size is $10 \times 9.70 \mathrm{~m}$; the height of the minare located to the left of the central horseshoe-shaped entrance, is $14 \mathrm{~m}$. It is known that the mosque was built during the reig of Abu Said Uthman, the thickness of the brick walls is $0.7 \mathrm{~m}$, there are 3naves( the central one is wider) but there is no an inner courtyard.

The Mechouar Mosque and minaret in Tlemcen (the end of the 10th -beginning of the 14th century) were built with stone and brick, were decorated with bricks, ceramic mosaic and glazed ceramics: the height of the minaret is $25.22 \mathrm{~m}$.

The main features: a hypostyle type, the similarity to the early hypostyle mosques: the main entrance through a square-shaped minaret, portal roofs with refters and tiles, , r m domes, domes are supported by pendendives, stucco moulding; the arches are based on round mate colums (the Hase Towrithe nice on concave consoles; a dacor and corarches on pylo consoles, a stalactite dome, of decorative finish in comparison with the second period.

Tlemcen is considered as the most stylistically holistic architectural complex of Algeria 5) the fifth period (the period of the first European colonization of the Spaniards and Portuguese) - the 11th historical period (late 15th16th centuries) - the influence of Spanish and Portuguese architecture and construction traditions, decoration

6) the sixth period (the period of eclecticism and the mixing of traditions during the reign of the Ottoman corsairs) - the 12th historica period (1554-1830):

The Ottoman period played a significant positive role in the development of the Islamic architecture of Algeria by introducing Ottomansty multi-domed mosques and constructing of a great number of new mosques (in At giers during the French occupation in 1830 there were 122 mosques, 13 of them -Friday Mosques):

16th century - the Great Mosque of Mascara the Al Ayn al- Bayda mosque in the city of Mascara, the Ali Khoja Mosque, the Great Mosque of the city of Touggourt;

16th -18th centuries - the Djama'a al-Djedid mosque (El Jedid, the Mosque of the Fisherman's Wharf) in Algiers (1660) - was built by Dey Mustafa Pasha, its size in plan is $39.50 \mathrm{x}$ $24 \mathrm{~m}$ and the height of the minaret is $30 \mathrm{~m}$. The mosque was built on the site of the Abu Inan Madrasa of stone, brick, marble and plas ter. The mosque has a basilica type of plan, has three naves, the naves are perpendicular to the wall of the Qibla, the central nave is decorated with a large dome, in four corners outside the space covered by the centra 
dome, there are four octagonal in plan smaller domes. The minaret is square in plan; its upper part with the roof lantern is crowned with a ceramic frieze.

The main features: the influence of Byzantine and partly derived from it Ottoman Islamic architecture in mosques, palaces, public buildings; a pyramidal composition with a central dome (sometimes oval in the Djama'a al-Djedid Mosque) with windows in the drum for uniform illumination, with a large interior space without pillars, surrounded by a gallery with interior spath small dom prest so-callo thin, with corical dentives and salls, athe and wood carvings in decor, type composition on wood and murals of timber parts. murals of timber parts.
It should be noted the main mosques of all periods of Algeria: the Sidi Ghanim Mosque in Mila, 678), the Shrine of Abu Madyan (the Sidi Abu Madyan mosque (1339), (Tlemcen), the Tlemcen congregational mosque (Jameh) (1082, rebuilt in 1136 and in the 13th century, a sample of the architecture of the Almoravids); the Great Mosque of Tlemcen (an example of the architecture of the Almoravids), The Ketchaoua Mosque (Ketchaua) (Algiers) (1612, a combination of Moorish and Byzantine architecture), the Djama'a al-Djedid Mosque ( Algiers) (1660, architecture of the times of the Ottoman Empire), the Great Mosque of Algiers (a sample of the architecture of the Almoravids).

3. The main types of planning solutions for Algerian mosques and the ritual significance of water

In the mosques of Algeria there are various planning schemes of mosques. The most ancient and most widespread is the Arabian hypostyle type of the mosque of the Syrian-Egyptian school (the Sidi Ghanim Mosque in Mila, 649). This type of mosque was evolved from the columned courtyard of the Prophet, later was e Mosque of the Prophet in Medina - with a courtyard of rectangular shape and a prayer hall divided into several paralle or perpendicular to the wall of Oibla separated by long paraller on mihro minab, may be wh spread may be wider tha the lat Another type of plan that occurs in the mosques of Algeria is the Ottoman type, which was formed under the direct influence of Byzantine traditions, in Turkey after the seizure of Constantinople in 1453. In this type of plan, the tangible direct influence of the constructive scheme and the voluminousspatial composition of the St. Sophia Cathedral in Constantinople is seen. The Ottoman mosques have a symmetrical two-part plan: the first rectangular volume, whichc adjoins the main entrance, is a spacious open courtyard, on four sides it is surrounded by galleries with small semi-domes, it is attached to a larger rectangular in terms of the volume,the actual prayer hall with an emphatically large central dome before the mihrab, around the central dome on the sides there are rows of smaller domes and pivots; it is the so called domed type of mosque.
The following variants of plans for mosques with domes are known:

Type 1 is a single-domed mosque, a dome before the mihrab in the centre of the prayer hall, occasionally in the back of the prayer hall (the Beni-Achir mosque);

Type 2 - a two-dome mosque, one dome in front of the mihrab, a second one or in the above the entrance

Type 3 - three-and multi-dome mosque of the Ottoman period.

The plans of Algerian mosques consist of the The plans of Algerian mosques

1) the courtyard with a fountain surrounded by galleries - a rectangular shape, square or irregularly shaped, which has a purely decorative significance in the mosques of the Maghreb type and serves for ritual ablution in mosques of the Ottoman type;

2) a prayer hall of a rectangular shape (the Great Mosque of Constantine (Emir Abdelkader Mosque 1), irregularly shaped or square (the mosque of Tafessera, the Mosque of Sidi Benaïssa, Tlemcen, the mosque of BeyMohammad al-Kabir in Tush, of various sizes - small, medium, large (the largest - in the Great Mosque of Algiers.) The naves of the prayer halls can be perpendicular and paralle to the wall of the Qibla

3) Mihrab - curved or polygonal niches in the back wall of the mosque - Qibla

4) Bearing columns of the interior, the prototype of which were palm pillars, which supported the canopy of the Prophet's prayer courtyard in Medina

courtyard in Medi

If you compare the types of plans of the most fa mous mo note the dominance of two man schemes a derivative of the Arabian hypostyle mosue, most often with naves, parallit the wall of Oibla, occasionly perpendicul, with or withOut an inner coutyard, rectanglar or ireguly shaped, (Sidi Okba Moclangular or iregularly in Ann (his Mosque, Sala Bey Mosque including the period of Oteserved at all periods Mosque of Mascara the Great Mosque of the city of Touggourt); and the derivative from the Romanesque, Byzantium and Ottoman architecture - the domed type of the plan, it was rare in the first period and was encountered in the east, which is explained by the influence of Byzantium (the Salah Bey mosque in Annaba), but is actively introduced during the reign of the Ottoman Empire (Ali Khoja Mosque, the Djama'a al-Djedid Mosque ( Algiers).
In contrast with mosques of a distinctive regional type, the chitectural and planning principles. Since the spread of the Khariijtes culture is connected with the period of the Persian dynasty of Rostemids, in order to understand the occurrence of leaks of their Islamic architecture, in particular in Gardaia, it is necessary to analyze the specific features of the pre-Islamic and Islamic architecture of Persia in order to establish the possibility of borrowing national architectural and construction sibility of bortiom the traditions from there. The possible presence of such influences the 作 niques and decorating methods were observed in the palaces niques and decorating methods were observed irab rulers after the Arab conquest of Persia.

As in other countries of the Islamic world, ritual ablution plays As in other countries of the lslamic world, ritual ablution plays an important role in the lslamic architectural school of Algeria. However, the process of ritual bathing in various Islamic countries is different: for example, in the Ottoman mosques (and in the mosques of the Ottoman period in Algeria), in the centre of the open courtyard there is a pool with a fountain, and there are special benches for ritual bathing around it, believers draw water from fountain, st down on benches and wash the face, hands and feet (shoes are first left in a specially designe place). But in the mosques of the Maghreb type in Algiers, the fountain cannot exist at all or it performs purely decorative function, since the ritual ablution is carried out under the cranes in special side galleries, separately men and women.

\section{Regional specificity of the architecture of mosques} in Algeria

Based on the analysis of the manifestation of national identity and external influences on the architecture of Algeria of different periods, four main arrays can be distinguished with the domination of certain architectural traditions:

1) the north part(the Adriatic coast) - mixing of Arab, Maghreb Ottoman, Spanish-Portuguese traditions (Algiers, Tenes)

2) the west part (the border between Algeria and Mor) 2) 2) Mascara, Tlemcen, the maximum preservation of the unique monuments of Islamic architecture):

3) the east part (the border between Algeria and Tunisia) the influence of Romanesque, Byzantine, Ottoman traditions ( Constantine, Annaba, Touggourt)

4) the central part (Kharijites) (M'zab) - the preservation of 4) the central part (Kharijites) ( $\left(M^{\prime} z a b\right)$ - the preservation of
the territory with a concentrated manifestation of the national the territory with a concentrated manifestation of the national
culture of the Kharijites, whose sources were, among other

culture of the Kharijites, whose sources we
things, Persian traditions ( city of Ghardaia).

Most of the country is a desert, the place of residence of nomadic Bedouin Tuareg tribes, so the cities there began to appear quite recently and the capital's ancient buildings of mosques were not preserved there.

Signs of the Maghreb-type mosque of Algeria:

in planning - the type of the Arabian hypostyle mosque with naves, parallel to the wall of the Qibla, where the central nave that leads to the mihrab can be slightly wider, with a court- yard or without a courtyard, a rectangular or rectangular plan with a cut one side, the inner courtyard can either can have a fountain that performs purely decorative, rather than ritual functions, or without it. Ritual ablution of persons, hands and feet believers make in the galleries on the sides, under the taps, separately men and women,

in the volume-spatial composition - a comin the facade forms, with a prismatic minaret, the facade forn, with a roof lontern, usualy without a conical ond The dome may or may not be, its availability is not an obligatory element, as in the Ottoman Istamic school, and is the avidence of the fact that the basis of the Taghreb Iste of school, where the dome is not the main characteristic element.

There is a similarity of layouts and volumespatial compositions of the Maghreb type in Algeria and neighbouring countries - Tunisia and and neighbouring countries - Tunisia commonality of traditions, as well as the ruling Berber dynasties.

The main features of the Kharijites type of the Algerian mosque:

in planning - the type of the Arab hypostyle mosque with naves, parallel to the wall of the Qibla, where the central nave that leads to the mihrab can be slightly wider, with an inner courtyard or without a courtyard; the plan is of irregular serrate form;

in the volume-spatial composition - a combination of especially simple geometric undecorated facade scale shapes, with especially hick (up to $70 \mathrm{~cm}$ ) walls as required by a hot climates, very small windows, with a minaret of a specific shape in the form of a minaret up prism with crown symbolizing hands, addressed with prayer to Allah.

The main features of an Ottoman-type mosque introduced from outside:

in planning - the dome type of the mosque the presence of the main dome surrounded by smaller domes and semi-domes, the infuence of Romanesque architecture and Christian temples of the Byzantine Empire; The presence of a courtyard with a pool for ritual ablution, which is carried out around the fountain on the benches.

in volume-spatial composition - dome composition, related to the Christian churches of Byzantium, cylindrical minarets with conical endings.

Compared with the background of planning, the volume-spatial composition and 
the forms of elements of Ottoman-type mosques in Algeria, which are evident understandable, related to the mosques in the Ottoman Empire, the sources of the Islamic architectural Kharijites-lbadis traditions are different from the Arab, from the Maghreb, and from the Ottoman traditions and require a deeper understanding.

\section{Conclusions}

1) The periodization of the construction of Algerian mosques differs from the historical periodization, since one architectural period can be combined for several historical periods. The difference lies in the fact that the historical periodization is performed in accordance with the change of the ruling dynasties, and the architectural periodization reveals the periods when changes occurred in planning, volume-spatial composition, elements' forms, structural schemes or the decoration of mosques of different periods. On the basis of such a comprehensive analysis, the regional identity of Algerian mosques and the main regional schools are determined, and the presence of external influences and borrowings from other countries is argued.

The Algerian mosques of the Almoravids period, Marinids and Abd al-Wadids (Zianides, Banu Zian) are concentrated in the city of Tlemcen. The mosques of the Ottoman peiod were preserved in the city of Algiers and Constantine.

2) The peculiarity of the Islamic architectural school of Algeria is that in some regions of the country (west, north-west there are signs of Maghreb culture, centre, valley of the M'zab River - signs of the Kharijites culture), there are territories with a concentration of architectural styles - expressers of the national identity of Algeria, but there are also regions with a mix of different architectural styles and with the concentration of alien styles imported from the outside (north, east signs of Arab and Ottoman culture, the influence of Roman and Byzantine traditions). Taking into account the special natural climatic conditions of Algeria (most of the country is desert Sahara and only Bedouin nomads historically lived there), there is a concentration of historic mosques of different periods in the north-west, north and east. There are certain differences in external influences on certain territories of Algeria:

- west, north-west (Tlemcen, Oran) - the impact of the architecture of the Cordoba Caliphate, Andalusia; the direct example is the Great Mosque of Cordoba in the Maghreb architectural and construction traditions; north, east, north east (Algiers, Constantine) - the influence of architecture of the Ottoman Empire, Romanesque and Byzantine traditions;

- the centre (the cities of the Kharijides-Ibadis in the valley of the M'zab River) - the impact of the Sassanid architectural and construction traditions, the manifestations of the Persian pre-Islamic architectural Parsee and Partee styles imported from the territories of Iraq, transformed in other climatic conditions and influenced by Arab and Maghreb architectural traditions .

\section{REFERENCES}

[1] Bartold, V. V. Orientation of the first Muslim mosques / Bartold, V. V. Works. - M., 1966. Vol. 6. - pp. 537-542.

[2] Varga, D. Ancient East / Varga, D. - Budapest: Corvina, 1985.-166 p.

[3] Muller A. The history of Islam from the foundation to modern times. (Trans., N. A. Mednikova(Ed.) Vol. 1-4. Moscow, 2004. Part 1 (Vol. 1-2), pp. 148-149.

[4] General Assembly - Refworld, access online: http:// www.refworld.org/cgibin/texis/vtx/rwmain/opendocpdf. pdf? reldoc $=$ y\&docid $=4 a 9 e 30752$ (assess 05.2018) 